\author{
St udia Philosophic a \\ Wr a t i s l a vi e n s i a \\ vol. XV, fasc. $4(2020)$ \\ https://doi.org/10.19195/1895-8001.15.4.1
}

\author{
KAMIL AKSIUTO \\ ORCID: 0000-0002-4768-8936 \\ Uniwersytet Marii Curie-Skłodowskiej
}

\title{
MacIntyre against the modern state
}

\begin{abstract}
One of the distinguishing features of Alasdair MacIntyre's political theorising is his trenchant critique of the modern state. The article aims to explore the underlying reasons behind MacIntyre's antistatism. Beginning with MacIntyre's critique of the traditional arguments justifying political obligation, it then proceeds to the crucial issue of politics of common good. The author argues that MacIntyre rejects the modern state as an instrument of politics of common good mainly for two main reasons: 1) the close partnership between the modern state and capitalism; 2) the bureaucratic and often unjustly coercive character of the modern state. The article concludes with several polemical remarks concerning MacIntyre's position.
\end{abstract}

Keywords: common good, communitarianism, MacIntyre Alasdair, modern state, political obligation

\section{Introduction}

There is an element of Alasdair MacIntyre's political theorising which deserves more attention than it has received both from his followers and opponents. What I have in mind is MacIntyre's critique of the modern state. There are several reasons why it merits attention. Firstly, it has been a remarkably stable element of MacIntyre's political outlook for at least 40 years, reappearing in his works in variations which differ in detail rather than in general tone. Secondly, MacIntyre is often associated with communitarianism, despite repeatedly protesting against this label. ${ }^{1}$ In his view it is precisely the suspicious attitude towards the modern

1 A. MacIntyre, "I'm not a Communitarian, but...", The Responsive Community 1 [3] (1991), pp. 91-92; idem, "Politics, Philosophy and the Common Good", [in:] The MacIntyre Reader, K. Knight 
state that forms one of the crucial differences between him and other theorists grouped in the communitarian camp. Thirdly, there are good reasons, quite apart from the typical interests of MacIntyrean scholarship, for examining his critique of the modern state. His views are likely to provoke disagreement, as indeed is the case with the author of this text, but they raise several issues which deserve to be addressed in their own right.

\section{Attempts to justify political obligation}

MacIntyre's critique of the modern state can be presented as an attack on the idea that citizens have a political obligation towards their respective governments. The debate concerning political obligation is itself very old, and can be traced at least as far back as to Socrates. ${ }^{2}$ The view held by the majority of the theorists involved in this debate has been that there is some special bond tying individuals to their political community. Political obligation consists in citizens being obliged to comply with the laws issued by the state authorities, to pay taxes, to perform military service and support their state in other ways. The conceptual correlate of this obligation is the right of legitimate governments to command and to enforce obedience if necessary. ${ }^{3}$

It would be a mistake, however, to assume that MacIntyre rejects political obligation in general. The target of MacIntyre's critique is not just any form of political organisation which can be called a state. His thesis is more restricted: it is the modern state, with its distinctive features, that in his view citizens have no moral obligation to obey. There is no place here for an exhaustive characteristic of this type of political entity, but it will perhaps suffice to note a few things. A typical modern state claims to have sovereign authority over a relatively large population inhabiting its territory. This entails that it has an exclusive claim to issue legislation and to enforce it within its borders. It also possesses a complex and pervasive bureaucratic apparatus for governing this population. Usually, although less commonly, it also takes the form of a nation state, that is, the majority of its population is supposed to form a nation.

There are several types of arguments mounted to justify political obligation towards the modern state which MacIntyre discusses and rejects. Before proceeding further, it is worthwhile presenting his criticism in more detail.

Firstly, there is a group of theories of political obligation which draws inspiration mainly from John Locke's account of the original contract. Obviously, contemporary exponents of consent theories do not maintain that there was a histor-

(ed.), Notre Dame 1998, pp. 243-246; idem, After Virtue. A Study in Moral Theory, Notre Dame 2007 (1981), pp. XIV-XV.

2 The term "political obligation", however, has a relatively brief history. It can be dated back to T.H. Green's Lectures on the Principles of Political Obligation in the late 19th century; see J. Horton, Political Obligation, London 1992, p. 71.

3 A.J. Simmons, Moral Principles and Political Obligations, Princeton 1979, pp. 195-196. 
ical contract between citizens and government. ${ }^{4}$ Nor do they claim that for a vast majority of citizens of contemporary states an act of voluntary, intentional, knowing and directly communicated consent to the authority of government could be detected. ${ }^{5}$ But drawing on Locke's concept of tacit consent attempts have been made to show that there are acts which can be interpreted as equivalent to consenting to a particular political authority. The most plausible candidates for such acts are either continuous residence in a given state or opportunity to participate in democratic elections. ${ }^{6}$ MacIntyre however rejects these arguments. Firstly, the account of tacit consent presupposes that a choice between two alternatives must always be voluntary. But this is clearly not the case, as it depends on the character of the alternatives. When a street mugger presents us with an alternative: "Your money or your life", it is hardly a situation of voluntary choice. Similarly, remaining in a given state does not signify consent given the material and immaterial costs of emigrating for the vast majority of people. Moreover, as MacIntyre notes: 'Nothing can count as my voluntary consent which is not in my power to withhold'. ${ }^{7}$ This cuts against the alleged tacit consent by having the opportunity to vote. If by voting I am expressing consent to whatever government will be formed as a result of elections, and by not voting I am apparently doing the same, it seems that there is no opportunity for me short of open rebellion to withhold my consent.

MacIntyre's critique of consent theories also contains an interesting historical side note. Locke seemed to believe that the legitimate scope of state power covers a fairly limited though vitally important set of functions, mainly those concerned with providing security of persons and property. As MacIntyre points out:

Since the eighteenth century [...] let alone since those very early times in which Locke imagined the making of the original compacts, the scope, functions and powers of government have changed more than Locke ever envisaged, the provision of public education, the promotion of full employment, the creation and sustenance of a variety of forms of welfare. And we generally regard government as legitimately entitled to coerce us in ways that Locke never envisaged: new and drastic forms of taxation, redistributions of wealth and property, regulation in the use of our property. ${ }^{8}$

This passage itself might sound a bit dated, but the point is that the scope of functions of government is constantly evolving under the influence of many factors, including economic trends. It seems implausible to suggest that ordinary citizens are in any strong sense consenting to these changes, whether we are talking about

4 Perhaps the most interesting recent attempt to make use of the resources of the consent tradition has been undertaken by David Estlund in his account of normative consent. See D. Estlund, Democratic Authority, Princeton-Oxford 2008, pp. 124-135. For a critique of Estlund's attempt to base political obligation on this notion see N. Frank, "Against Normative Consent", Journal of Social Philosophy 47 [4] (2016), pp. 470-487, https://doi.org/10.1111/josp.12174.

5 A.J. Simmons, op. cit., p. 77.

${ }^{6} \mathrm{I}$ am leaving aside the view that participation in democratic elections, not just merely an opportunity to participate, constitutes a form of tacit consent. For the obvious difficulty for the supporters of that view is that in many democratic countries the electoral turnout remains relatively low and thus a large portion of the electorate which does not vote would have no political obligation.

7 A. MacIntyre, "Philosophy and Politics", [in:] Philosophy and Human Enterprise, USMA Class of 1951 Lecture Series, 1982-3, West Point 1984, p. 143.

8 Ibid., p. 137. 
the growth of state bureaucracy and its coercive power, or the abdication of government from performing some tasks.

An altogether different group of accounts tries to justify political obligation drawing on perhaps the most influential teleological moral theory of modern times - utilitarianism. Already the founders of utilitarian thought, Jeremy Bentham and James Mill argued that government is an instrument of securing the greatest happiness of the greatest number. For instance, Mill claimed in his essay Government, that without political authorities natural egoism would lead to conflict between individuals, each striving to enslave others and take possession of the fruits of their labour. Thus the sole purpose of government is:

to make that distribution of the scanty materials of happiness which would insure the greatest sum of it in the members of the community taken altogether, preventing every individual or combination of individuals from interfering with that distribution or making any man to have less than his share. ${ }^{9}$

MacIntyre criticises utilitarianism quite extensively in many of his writings, but fortunately the details of his attack are not crucial here. Two points need to be highlighted, nevertheless. Firstly, the standard by which utilitarians judge any government, the greatest happiness of the greatest number, is too indeterminate to yield answers to many questions concerning political authority and its legitimate scope. This is mainly due to the fact that even if happiness is conceived as satisfaction of desires and preferences, human desires and preferences are too heterogeneous to be all reduced to a single scale. ${ }^{10}$ Secondly, even if the former obstacle could be overcome, the utilitarian account of political obligation would still fail, since it does not meet what A.J. Simmons called the "particularity requirement". The traditional view of political obligation has been that an individual has an obligation not to just any political community, but: "to one particular state above all others, namely the state in which he is a citizen". ${ }^{11}$ The moral bond between an individual and the state belongs to the class of special relationships, not unlike in the case of obligations generated by family and friendship. Therefore also the obligation towards one's state has a moral weight independent of whatever general moral considerations one might have. ${ }^{12}$ It should be clear already why utilitarianism cannot meet that requirement. For if the states are to be judged only by whether they contribute to the maximisation of general happiness, their value is purely instrumental. There can be no special obligation binding the citizens to their political authorities. ${ }^{13}$ In some cases, it might be even against the dictates of utilitarian morality to support one's state against another, say during a war, if the opponent is much more likely to promote general happiness.

9 J. Mill, "Government", [in:] The Political Writings of James Mill: Essays and Reviews on Politics and Society, 1815-1836, D.M. Hart (ed.), Indianapolis, IN 2013, p. 263, http://oll-resources.s3.amazonaws.com/titles/2520/Mill_1624_EBk_v7.0.pdf (accessed: 28.11.2020).

10 A. MacIntyre, "Philosophy...", pp. 144-145.

11 A.J. Simmons, op. cit., p. 32.

12 This is obviously not to say that the obligation of the citizen to his/her state always overrides general moral duties.

13 A. MacIntyre, "Philosophy...", pp. 145-146. 
MacIntyre also deals with what can be described as the public interest argument. ${ }^{14}$ In a compressed form the argument states that all individuals, independent of their particular ends and interests, need certain goods in order to live acceptable lives and effectively pursue those ends and interests. Among such goods indispensable to all individuals, despite them not sharing any substantial idea of what constitutes a good life, one can list: personal protection, national defence, law and order, public health (or at least some aspects of it), protection from natural disasters, transportation infrastructure. ${ }^{15}$ Goods of this kind are frequently referred to as public goods. The argument then moves from the assumption that the state is the only entity which can provide public goods (or at least the most efficient in that regard) to the conclusion that citizens should comply with the law and state's institutions. Public goods are obviously very important, and MacIntyre does accept that the state should provide at least some of them. However, he finds this justification of political obligation unpersuasive for two reasons. The first one is the free-riding problem. If citizens share nothing in common other than the need for certain public goods, then for an individual it is perfectly rational and beneficial to withhold his or her contribution to the provision of public goods (such as the cost of buying a ticket), as long as there is a good chance that a penalty can be avoided. Such acts of taking advantage of others' compliance with legal rules need not lead to any serious disruption in the scheme of securing public goods, especially given the size of populations of modern states. The second reason why the public interest argument fails is the fact that there are some jobs which require the occupants to, if necessary, sacrifice their life or health for the good of others. Simply put, every society needs soldiers, policemen, firefighters etc. Yet again, if the only bond between citizens is that of the common interest in public goods, it seems irrational for an individual to bear such a high cost. But all governments demand and must demand from some to make such sacrifices. The state cannot therefore rely solely on the public interest argument, for otherwise, as MacIntyre puts it: "Being asked to die for it would be like being asked to die for the telephone company". ${ }^{16}$ It follows that the very existence of the state will be in danger: "unless a significant proportion of its members are unconvinced that the only justification for accepting and upholding political society and political authority is individualist and minimalist". ${ }^{17}$ The insufficiency of the public interest argument is therefore tacitly confirmed by the modern state's appeal to other considerations in order to justify its authority.

${ }^{14}$ M.C. Murphy, "MacIntyre's Political Philosophy", [in:] Alasdair MacIntyre, M.C. Murphy (ed.), Cambridge 2003, p. 154.

15 This list of public goods is inspired by (although not identical with) the list provided by G. Klosko, Political Obligations, New York 2005, pp. 24-40. Neither Klosko, nor the author of this paper claim to be presenting an exhaustive list of public goods which are most efficiently secured by the state.

${ }^{16}$ A. MacIntyre, "Poetry as Political Philosophy: Notes on Burke and Yeats", [in:] idem, Ethics and Politics. Selected Essays, Vol. 2, Cambridge 2006, p. 163.

17 A. MacIntyre, "Politics, Philosophy...", p. 242. 


\section{The image and reality of democratic politics}

There is yet another argument which aims to justify the state's authority and which MacIntyre sometimes considers. In contrast with the public interest argument it concerns not all modern states, but only democratic ones. Let us call it then the democratic authority argument. Although it can be easily run together with the consent account of political obligation, the point here is not so much about individual consent as about collective self-determination. If I think of myself as a member of a political community which is democratically structured, it is possible for me to view the policies enacted by the government not as an purely external and coercive imposition of somebody's will on me. Instead, despite disagreeing with the policies in question, I might perceive them as the result of a fair collective decision-making process in which I myself participated. Despite the differences of opinion between me and the majority of my compatriots, I still should respect the decision "we" took. Now, in discussing this argument MacIntyre reveals some of the important sources of his discontent with the modern state. Therefore, his exposition and critique of the democratic authority argument deserves a more thorough treatment as well as some polemical remarks.

In democracies, policies pursued by governments are to be taken as an extension of the decisions undertaken by the citizens. This is mainly due to free, competitive and regularly held elections as well as certain freedoms, like freedom of speech or freedom of assembly, which liberal democracies guarantee. The only problem with this line of reasoning, according to MacIntyre, is that it mistakes the self-image of modern (typically Western) democracies for their social and political reality.

There are two main points here worth highlighting. Firstly, contemporary democratic politics is insufficiently deliberative. The great hope of the Enlightenment was the gradual proliferation of what Kant called "public use of reason". Such reasoning is modelled by Kant via the example of a scholar inviting the "reading public" to impartially and objectively examine his arguments. An enquiry of this sort is supposed to be free of the dictates of authority, for the only thing that matters are standards of reason as such. In Kant's times the twin ideals of the "public use of reason" and of the "reading public" were embodied in various societies and associations all over Europe, from St. Petersburg to Glasgow. ${ }^{18}$ It was the hope of the philosopher from Königsberg that this mode of enquiry would gradually become a manner of proceeding in other spheres of activity, government included. Yet, the actual development of modern states, even democratic ones, has lead in a different direction altogether. According to MacIntyre, currently there is little or no place for systematic debate between citizens which would allow them to exercise their rational capacities and reach a reasoned agreement. Moreover, even if episodes of such debate occur, discussing controversial philosophical and moral issues is to be avoided as potentially polarising and dangerous for the social order. This is obviously not what Kant expected. Neither is this politics in

18 A. MacIntyre, "Some Enlightenment Projects Reconsidered", [in:] idem, Ethics and Politics..., p. 178. 
the Aristotelian sense of a practice which allows people to deliberate what place various goods should occupy in their common life. Politics in modern democracies instead is one more compartmentalised activity. It is practised on a daily basis by a separate class of people and governed by rules and standards different from those in other spheres. As MacIntyre puts it:

What is lacking in modern political societies is any type of institutional arena in which plain persons - neither engaged in academic pursuits nor professionals of political life - are able to engage together in systematic reasoned debate, designed to arrive at a rationally well-founded common mind on how to answer questions about the relationship of politics to the claims of rival and alternative ways of life, each with its own conception of the virtues and of the common good. ${ }^{19}$

Secondly, this outcome is not accidental. Although democratic states in general respect a certain form of formal equality of citizens in the public sphere, the distribution of wealth and opportunities is far from equal. The advantage in financial resources and opportunities is easily convertible into political power. Therefore, politics in modern democracies is shaped by a set of elites. They consist of those with expertise in a given field, specialists in political marketing, media tycoons, affluent individuals and corporate donors to parties and politicians, etc. The boundaries between these groups are often blurred, which makes it harder to assess their influence on democratic politics. MacIntyre's point is that the extent of actual collective self-determination in contemporary democracies is very limited. In one sense, citizens of democratic countries are obviously free to select between various political platforms and programmes. Yet, the range of their choices is not determined by them, it is controlled, if not fully, by a "set of interlocking elites, political, financial, cultural and media elites". ${ }^{20}$ Unsurprisingly then, MacIntyre also maintains that: "Politically, the societies of advanced Western modernity are oligarchies disguised as liberal democracies". ${ }^{21}$ This diagnosis of contemporary politics is clearly indebted to the tradition of thought developed by Robert Michels and similar theorists who stressed the inevitable oligarchic trend in large-scale, complex political organisations. ${ }^{22}$

Let us first deal with the contention that modern democracies are not sufficiently deliberative. It is one thing to claim that many important political decisions are not a result of (or are not influenced by) deliberation between the citizens, it is quite another to explain what standards such deliberation would have to meet to count as successful and authentic. It is by no means clear what exactly MacIntyre takes such standards to be. Does he mean that all of the participants in the debate should have an equal opportunity to express their opinions? Is the result of the deliberation supposed to be a unanimous or nearly unanimous decision? That surely can happen only in very small communities with certain additional

19 A. MacIntyre, "Politics, Philosophy...", p. 239.

20 A. MacIntyre, Ethics in the Conflicts of modernity: an Essay on Desire, Practical Reason and Narrative, Cambridge 2016, p. 127.

21 A. MacIntyre, "Politics, Philosophy...", p. 237.

22 See R. Michels, Political Parties: a Sociological Study of the Oligarchical Tendencies of Modern Democracy, New Brunswick 1999 (1962). I owe this point to the suggestion of doctor Peter Wicks from the Elm Institute. 
characteristics. Indeed, MacIntyre's examples of successful deliberation are drawn from the context of small groups, be it a parish, a village or a hospital. As he rightly notes, the very size of the populations of a vast majority of modern states would make recurrent deliberative engagement of this kind impossible. ${ }^{23}$ But it simply begs the question to place the bar so high. I see no reason to assume that the deliberative process cannot count as successful when the issue at stake has been extensively debated with a fairly objective media coverage of the debate and with an inclusion of voices and arguments of representatives of various groups. Granted that this does not happen often and does not solve all the problems concerning deliberation, it does seem to me like a demanding but not an unrealistically high standard of common reasoning occurring in larger groupings, even at the state level.

Moving on to the claim that contemporary democracies are in fact oligarchic, in my view MacIntyre has a very strong case here. What is nevertheless disappointing is the lack of reference in his work to empirical evidence which would help to substantiate this claim. Not that there is a shortage of works which could be used to support it. ${ }^{24}$ However, for at least some of MacIntyre's sympathisers there is a more serious problem lurking here. In an insightful article, Thomas Hibbs makes several charges against MacIntyre's political theorising. One of his crucial objections is that MacIntyre wholly neglects Aristotle's analysis of regimes and as a result his approach ends up being curiously undialectical. It is obviously true that according to Aristotle oligarchy belongs to defective regimes. Yet, even the latter are carefully interrogated by Aristotle, as they approximate what justice requires, although only in a partial and defective way. This approach does not imply an uncritical attitude, Hibbs argues that Aristotle aims to explain how perverted regimes fail, by exhibiting: "the way in which a neglect of other goods, especially virtue, is deleterious not just to the flourishing but to the very survival of the regime". ${ }^{25}$ Yet, MacIntyre does not follow in Aristotle's footsteps since he does not concern himself with a nuanced analysis of oligarchic character of contemporary democracies. For instance, he does not seem to ever entertain the question of whether oligarchic trends do not occasionally bring some good consequences. My point is not that MacIntyre should answer this question in the affirmative, but rather that he should take it seriously, instead of going for a rhetoric of unmasking and sweeping condemnation. Undoubtedly, in that respect he remains a more faithful pupil of Marx than of Aristotle.

23 A. MacIntyre, Dependent Rational Animals. Chicago-La Salle 1999, p. 132.

24 See M. Gilens, B.I. Page, "Testing Theories of American Politics: Elites, Interest Groups, and Average Citizens", Perspectives on Politics 12 [3] (2014), pp. 564-581, https://doi.org/10.1017/ S1537592714001595; L.M. Bartels, Unequal Democracy: The Political Economy of the New Gilded Age, Princeton 2016 (2008).

25 T.S. Hibbs, "MacIntyre, Aquinas, and Politics", The Review of Politics 66 [3] (2004), p. 373. 


\section{Modern state and the common good}

Apart from all the previously discussed attempts to justify political obligation there seems to be yet another possibility. Moreover, this option is recognised, but vehemently rejected by MacIntyre. In a revealing passage he states: "The modern state [...] behaves part of the time towards those subjected to it as if it were no more than a giant, monopolistic utility company and part of the time as if it were the sacred guardian of all that is most to be valued". ${ }^{26}$

The first part of this quote concerns the role of the modern state as a provider of public goods. But the second one "the sacred guardian of all that is most to be valued"-includes, I think, the claim that the modern state also promotes the common good of all citizens. According to MacIntyre there is then a fundamental contradiction in the ways in which the modern state presents itself to those under its rule. There can be no doubt which of the two modes of self-presentation is in his opinion a mask and which one a true face. In Dependent Rational Animals MacIntyre claims that:

the shared public goods of the modern nation state are not the common goods of a genuine nation-wide community, and when the nation state masquerades as the guardian of such a common good, the outcome is bound to be either ludicrous or disastrous or both. [...] insofar as the rhetoric of the nation-state presents it as something that is indeed, in the stronger sense, a common good, that rhetoric is the purveyor of dangerous fictions. ${ }^{27}$

Yet, these are merely assertions, and what exactly about the modern state makes it so unfit as an instrument of pursuing the common good of the whole polity?

In order to answer this question we must first know what MacIntyre means by common good? We are accustomed to thinking that common good of a given association means simply an aggregate of the goods of all individuals belonging to it. MacIntyre however claims that at least in some associations, the original ends and desires that people bring into them are transformed by engaging in cooperative activities with other members. Therefore common good of such an association cannot be construed as the sum of the goods of individuals independent of their membership in it. For instance, the common good of a family is not an aggregate of the goods of its members simply qua individuals, as if there were no bonds of kinship, no familial affections between them and no common ends. Instead, the good of the whole unit partly constitutes the individual goods of particular family members. The family is not the only social unit of this sort. Many practices, in a specific sense that MacIntyre ascribes to this term, like playing in a string quartet or farming, are cooperative activities aimed at achieving goods which are internal to them. ${ }^{28}$ The important point here is that while individuals enter a given practice with multifarious desires and ends, at some point they (hopefully) come to realise that the excellence in that practice is their common good. Furthermore, this com-

\footnotetext{
26 A. MacIntyre, "The Theses on Feurbach: a Road not Taken", [in:] The MacIntyre Reader, p. 227.

27 A. MacIntyre, Dependent..., pp. 132-133.

28 A. MacIntyre, After Virtue..., pp. 187-188.
} 
mon good is not diminished by the fact that not everyone can become a masterful string player, farmer etc. Unsurprisingly, in the tradition of thought within which MacIntyre locates himself, the common good of a political society should also be construed in this way. He invokes an unmistakably Aristotelian conception of politics as a supreme practice through which citizens can actualise their capabilities as rational agents and order various goods in their common life.

We have already seen that according to MacIntyre contemporary democratic politics is very far removed from that Aristotelian ideal. But there are deeper reasons why in democracies politics functions in the way it does.

First, modern states are typically capitalist, even those with purportedly socialist economies are nowadays quite hospitable to capitalism. This is understandable given that the strategic interests of the states and global markets to a large extent coincide. State institutions for instance require financial resources which are generated through operations on those markets, ${ }^{29}$ while international corporations need a framework of rules and regulations typically provided by states. This does not preclude occasional conflicts between state and corporate actors, yet such occurrences do not in general undermine the identity of needs: "for capital formation, for economic growth, and for an adequately trained but disposable labour force, whose members are also compliant consumers and law-abiding citizens". ${ }^{30}$ Hence both state institutions and markets usually collaborate in limiting the agency of individuals and groups, in disempowering them. For instance, the already mentioned oligarchisation of democracies results from an unequal distribution of power, wealth, social and cultural capital generated largely by the "indissoluble partnership" between modern states and capitalism. ${ }^{31}$

Second, politics in the Aristotelian sense endorsed by MacIntyre is conditioned upon a widely shared, even if originally rough and ready, conception of what it means for human beings to live a good life. Without appeal to such a standard of human good it would be impossible to rationally and objectively solve disagreements within the polity. But according to MacIntyre modern societies, in contrast with their predecessors, are characterised by a lack of agreement on any substantial conception of a good life. The extent of moral disagreements in modern societies is precisely one of the driving factors behind the exclusion of comprehensive conceptions of a good life from the sphere of liberal-democratic politics. In the absence of a moral consensus on some substantial idea of a good life, social cooperation has to be secured by other means. Here again the modern state enters the picture. It is a large, hierarchical and bureaucratic organisation ideally suited to the "man-

${ }^{29}$ MacIntyre's attitude towards forms of economy based on market exchange is ambiguous. He does admit that in the small-scale (or even medium sized) communities with a wide distribution of ownership of the means of production, market exchange is not only acceptable, but necessary. He also praises the economic ideals of the distributists: A. MacIntyre, "Three perspectives on Marxism: 1953, 1968, 1995", [in:] idem, Ethics and Politics..., p. 148. It is however clear that for MacIntyre the advanced capitalist markets are incompatible with those ideals and that they are detrimental to the continuous existence and flourishing of many small scale communities.

30 A. MacIntyre, "Toleration and the Goods of Conflict", [in:] idem, Ethics and Politics..., p. 211.

31 Ibid., p. 210. 
agerial mode" of conducting politics. ${ }^{32}$ By managerial I mean mainly two things. Firstly, the modern state is supposed to be neutral between various conceptions of a good life. It claims to focus chiefly on the provision of public goods which all citizens need independent of their individual ends. Yet, this neutrality is a charade as it presupposes a highly individualistic conception of the self and moral life. Secondly, since in social life conflicts between various moral considerations arise, for instance between individual rights and general utility, the modern state's role is to "manage" these conflicts, that is to neutralise them. Since there is no moral consensus in the society to fall back upon, the modern state enforces certain rules, compromises and bargains. It imposes an order on the heterogeneity of conflicting social and economic interests. In this way it prevents protagonists of these conflicts from questioning the very nature of the political, economic and social status quo. Already in After Virtue MacIntyre diagnosed late modernity with the disease of "bureaucratic individualism". ${ }^{33}$ While modern people often think of themselves as autonomous agents freely determining the course of their lives, at the same time they are frequently passive subjects when faced with the power wielded by state and corporate institutions. ${ }^{34}$

However, the modern state cannot present itself to citizens merely as a bureaucratic machine. MacIntyre emphasizes that:

In any society where government does not express or represent the moral community of the citizens, but is instead a set of institutional arrangements for imposing a bureaucratised unity on a society which lacks genuine moral consensus, the nature of political obligation becomes systematically unclear. ${ }^{35}$

In other words, the modern state in order to function must obscure its true nature, it requires an ideological justification of its authority. And sometimes it masquerades as an embodiment of a moral community, where in fact there is none to be found on the level of the whole society. ${ }^{36}$ As Mark C. Murphy aptly captured this aspect of MacIntyre's views: "the state can survive only by having citizens that are deceived". ${ }^{37}$

32 The managerial character which MacIntyre ascribes to the modern state is explored in greater detail in K. Breen, "The State, Compartmentalization and the Turn to Local Community: A Critique of the Political Thought of Alasdair MacIntyre", The European Legacy 10 [5] (2005), pp. 487-488, https://doi.org/10.1080/10848770500173722. His analysis brings out the importance of MacIntyre's notion of compartmentalization for his critique of the modern state much more fully than my attempt in the present article. Nevertheless, it seems to me that my conclusions are generally complementary to Breen's.

33 A. MacIntyre, After Virtue..., p. 35.

34 This view echoes Max Weber's characterization of bureaucratic authority in modernity.

M. Weber, The Protestant Ethic and the Spirit of Capitalism, London-New York 2001, pp. 123-124.

35 A. MacIntyre, After Virtue..., p. 254.

36 A. MacIntyre, "Politics, Philosophy...", p. 236.

37 M.C. Murphy, op. cit., p. 155. 


\section{MacIntyre as a critic of communitarianism}

MacIntyre has repeatedly distanced himself from the communitarian label. In his view, thinkers such as Amitai Etzioni, Charles Taylor and Michael Walzer ${ }^{38}$ are far too well-disposed towards the modern state and its politics. It is easy to construe the communitarian position as diametrically opposed to the (broadly) liberal one, by contrasting group loyalties with individual rights or socially particularized conceptions of the good with universal principles of justice. Yet, MacIntyre is convinced that there need not be any fundamental contradiction, both on the theoretical and practical level, between proponents of liberalism and their selfstyled communitarian critics: "there are certainly some versions of liberal theory and some formulations of communitarian positions which are such that the two are not only not in opposition to each other, but neatly complement one another". ${ }^{39}$ Moreover, in his view, the misleading opposition between liberalism and communitarianism obscures the fact that the latter accepts the crucial limitations of politics in contemporary liberal democracies. Communitarians are often associated with stressing the value of family ties, group solidarities, of ways of life and traditions which would be doomed to wither away in an unhospitable social environment. However, MacIntyre argues that: "the values of communitarianism are [...] to be found in the state's ragbag of values and they were there long before the name 'communitarianism' was given to them". ${ }^{40}$ The modern state is happy to appeal from time to time to such values, but whenever it does so, it instrumentalises them for some purpose. Moreover, the actions of the state apparatus justified by invoking such values often do harm to the credibility of the latter.

As a result, MacIntyre strongly opposes any views which give the task of the promotion of such lofty goals to the modern state. He does indeed affirm the Aristotelian conception of politics in which the goal of the polity and its authorities is to educate citizens so that they become virtuous. But the modern state does not resemble Greek poleis or any similar form of political organisation and therefore it would be both counterproductive and dangerous to invest it with such prerogatives. The curious position of MacIntyre is well captured in his own admission that: "the power of the liberal individualist standpoint partly derives from the evident fact that the modern state is indeed totally unfitted to act as moral educator of any community". ${ }^{41}$ Therefore, he is also prepared to side with liberals against communitarians, arguing that: "the state must not be allowed to impose any one particular conception of the human good or identify one such conception with its

38 MacIntyre does not always make it clear who exactly are his adversaries when criticising contemporary communitarianism. Yet, he has engaged critically with Charles Taylor and Amitai Etzioni, hence it seems justified to mention them by name. While to the best of my knowledge MacIntyre did not explicitly criticised Michael Walzer's views, Walzer with his attachment to the American conception of the nation and citizenship seems to be a very plausible target of some of MacIntyre's polemics. I am leaving here aside the question of whether the latter's characterization of the views of the above-mentioned thinkers is adequate.

39 A. MacIntyre, "Politics, Philosophy...", p. 244.

40 Ibid., p. 245.

41 A. MacIntyre, After Virtue..., p. 195. 
own interests and causes. It must afford tolerance to a diversity of standpoints". ${ }^{42}$ While many liberals would agree with that statement because of their commitment to neutrality of the state between different conceptions of the good, MacIntyre claims that such neutrality is a fiction (although a politically important one). Precisely because the modern state cannot be neutral between competing conceptions of a good life, the task of moral education should be decentralized to various smaller groups, rather than left to the state.

In order to sum up MacIntyre's critique of communitarianism, a brief historical analogy, with a hint of irony, might be illuminating. Towards the end of the 19th century the socialist movements split into two camps. Some of socialists became reformists, they hoped that the rules of parliamentary democracy and gradual changes would make it possible to move from capitalism to socialism or, at the very least, to remedy the most severe injustices of the former. The other camp of revolutionary socialists maintained that it is impossible to change the capitalist system from within and that in effect reformists are traitors of the socialist cause. In a good old Leninist idiom the reformists were "objectively guilty" of collaboration with capitalism, even if subjectively they were well-intentioned. Now, it is hard to avoid the impression that MacIntyre is seeing communitarian acceptance of the modern state (and of capitalism as well) in a similar way to the one in which revolutionary socialists saw their former comrades who had joined the ranks of reformists.

\section{Critique of MacIntyre's antistatism}

I would like to identify what seems to me the three main lines of criticism of MacIntyre's antistatism that might be pursued and developed. Although logically independent they can be run together in order to question his position.

Firstly, it might be argued that MacIntyre's antistate rhetoric is nothing but radical posturing. For it is not clear what his arguments are supposed to change in practice, especially regarding day-to-day relations between citizens and states. MacIntyre's predicament here is similar to that of the so-called "philosophical anarchists". ${ }^{43}$ The latter term signifies a group of thinkers who argue that there is no political obligation, yet at the same time they do not encourage individuals to rebel against government and its laws, at least not in a typical situation. There might be no moral obligation to comply with the law just because it was issued by the state, yet there are other reasons, especially prudential ones, to abide by

42 A. MacIntyre, "Toleration...", p. 213. In a very interesting footnote Ronald Beiner gives an account of a discussion he had with MacIntyre in which the latter admitted that he is more radically antistatist than liberals. See R. Beiner, "Community versus Citizenship: MacIntyre's Revolt against the Modern State", Critical Review: A Journal of Politics and Society 14 [4] (2000), p. 476, https://doi. org/10.1080/08913810008443569.

43 Among the theorists associated with philosophical anarchism the most influential figures are A. John Simmons, Robert Paul Wolff and Leslie Green. The origins of the philosophical anarchism can be traced back to the publication of R.P. Wolff, In Defense of Anarchism, Berkley-Los Angeles-London $1998(1970)$. 
it. Thus an obvious question arises, even if what philosophical anarchists claim is true, does this make any practical difference for the citizens? MacIntyre is open to the same charge, as he is encouraging us to as far as possible abstain from any dealings with the modern state, but not to actively fight it. In fact, he even grants that there are certain very important goods which can be only obtained by complying with the state:

the rule of law, so far as it is possible in a modern state, has to be vindicated, injustice and unwarranted suffering have to be dealt with, generosity has to be exercised, and liberty has to be defended, in ways that are sometimes only possible through the use of governmental institutions. ${ }^{44}$

Again, what is the point of antistate theorising if in the end it seems to leave both the citizens and the state more or less in the same place as before the critical reflection was initiated? To this a notable philosophical anarchist A.J. Simmons replies that not everything remains unchanged, if philosophical anarchism is true then at least "it effectively removes any presumption in favour of obedience to established authorities". ${ }^{45}$ In a similar spirit MacIntyre might reply that although he is not encouraging citizens to overthrow governments, he is nevertheless recommending a prudent attitude towards the state, so that we accept only those compromises with it which are inevitable. Above all, this attitude should protect us against self-deception concerning the nature of the state and our duties towards it. Yet, some doubts remain over the coherence and stability of this position, especially since as citizens we are following state regulations in countless trivial situations, usually unreflectively. ${ }^{46}$

The second line of criticism is the following: MacIntyre's theorising leaves him without any political alternative for the modern state. As Ronald Beiner aptly observed, MacIntyre offers an Aristotelianism without a polis. ${ }^{47}$ MacIntyre would obviously protest that Aristotelian politics can find a place in a modern world in grassroots, local communities of virtue. But there are many questions concerning the type of political organisation he has in mind. Firstly, could such communities sustain and reproduce themselves? For instance, MacIntyre praises the communities of hand-loom weavers of Lancashire and Yorkshire at the turn of the eighteenth and nineteenth century. However, the hand-loom weavers could sustain their common life for barely a generation. ${ }^{48}$ This is not merely a matter of poor choice of example, for as MacIntyre himself acknowledges, the communities he envisages: "can never [...] aspire to achieve the levels of economic and technological development of advanced modernity". ${ }^{49}$ The picture of communal life he paints, as Keith Breen notes, has clearly pre-modern, even pre-Aristotelian undertones, also with

44 A. MacIntyre, After Virtue..., p. 255.

45 A.J. Simmons, op. cit., p. 200.

${ }^{46}$ For instance: traffic rules, tax regulations on income and purchases, formalities of contract law. See V.B. Lewis, "The Common Good against the Modern State? On MacIntyre's Political Philosophy", Josephinum Journal of Theology 16 (2009), pp. 374-375.

47 R. Beiner, op. cit., p. 474.

48 T.S. Hibbs, op. cit., p. 372.

49 A. MacIntyre, "Politics, Philosophy...", p. 250. 
regard to its economic structure. ${ }^{50}$ This makes it dubious whether such communities could withstand the pressure of the modern world with its current political and economic organisation.

But even if we allow that the communities MacIntyre has in mind could survive in relative independence from the state and market, could they really be called political, in the Aristotelian or any other sense? I have already alluded to their insufficiency, especially economic one. MacIntyre also seems to take for granted that they would enjoy a kind of broad legal autonomy that would allow them to issue their own legislation. Yet, nowhere does he explain how is this is to become possible within the jurisdiction of the modern state with its unified legal framework. Furthermore, in the Aristotelian tradition political communities, as contrasted with subordinate forms of human groupings, can justifiably use coercion in their internal and external relations. ${ }^{51}$ In other words, they can justifiably enforce legal norms and punish crime as well as wage wars. It is hard to see how any of the communities which MacIntyre mentions as approximations of his ideal should, or even could, aspire to do that.

Finally, as a way of introducing the third line of criticism, it should be noticed that in his attack on the modern state MacIntyre relies heavily on elements of Marxism which he never completely abandoned. What I primarily have in mind is Marx's account of the relationship between the civil society and the state. According to Polish philosopher Leszek Kołakowski:

To Marx the state [...], far from being a neutral mediator, is the tool of some particular interests disguised as the illusory universal will. Man as a citizen and as a private person is two different and separated beings, but only the latter, the member of the civil society, is the "real" concrete being; as a citizen he participates in the abstract community owing its reality to ideological mystification. [...] Modern societies, having abrogated the direct political validity of class stratification, split social life into two realms and this division is carried over into each individual existence; it became a contradiction within every human being, torn between his status as a private person and his role as a citizen. ${ }^{52}$

Consequently, Marx thought that Hegel was gravely mistaken in supposing that the state is an embodiment of ethical community, that its functionaries are the only social strata capable of subordinating particular social interests (including their own interests) to the universal good. ${ }^{53}$ It is hard to determine precisely to what extent MacIntyre remains committed to the Marxist goal of healing the split between particular and universal by overcoming the separation of the civil society from the political organisation. He seems to have grown disillusioned with the means of obtaining this end that Marxist socialism historically used. But at the same time MacIntyre preserves basically intact the negative side of Marx's analysis of the state and its ideological role. This Marxist trope is also reinforced by his insistence

50 K. Breen, op. cit., pp. 495-496.

51 T. Osborne, "MacIntyre, Thomism and the Contemporary Common Good", Analyse Er Kritik 30 [1] (2008), pp. 84-87, https://doi.org/10.1515/auk-2008-0105.

52 L. Kołakowski, "The Myth of Human Self-Identity. Unity of Civil and Political Society in Socialist Thought", [in:] The Socialist Idea: A Reappraisal, L. Kołakowski, S. Hampshire (eds.), London 1974 , p. 20.

53 Ibid., p. 19. 
on the already mentioned "indissoluble partnership" between the modern state and capitalist markets. ${ }^{54}$

This Marxist premise of MacIntyre's theorising does seem rather unrefined, even if it contains some truth. It results in an a priori assumption that whatever the state does by invoking the common good is simply an ideological smokescreen that disguises some particular interests. Yet, in Dependent Rational Animals MacIntyre himself praises those who were involved in the passage of Americans with Disabilities Act. ${ }^{55}$ On the consistently individualistic standpoint, someone who is not disabled can have a moral duty towards those so afflicted either if he happens to choose to be so morally bound or due to the natural duty of justice. If, however, we adopt the perspective of a common good, an able-bodied individual has a duty towards disabled members of his or her society independent of such considerations. An avoidable suffering of the disabled or injustice towards them constitutes harm not only to them, but also to those living in the same society who were lucky enough to avoid disability. Perhaps it is naive to suppose that the passage of Americans with Disabilities Act was a result of taking such considerations into account rather than simply of the bargaining between competing interests. However, does this case not suggest that occasionally the modern state, even in spite of itself, can serve the common good?

Furthermore, I will now argue that there is a particular type of community with a common good that can be promoted by the state. I am thinking about nations. It is after all not an accident that most of the contemporary states take the form of nation states. MacIntyre's objections to this line of thought are familiar. He associates the idea of a nation with volk, a pre-rational model of community and a very bad guideline for politics, no doubt. ${ }^{56}$ Moreover, at least sometimes he does seem to suggest that in the modern world national bonds have not only been weakened, but thoroughly dissolved. ${ }^{57}$ Thus, whenever the state invokes the common good of a nation, we are back to the Marxist thesis about the ideological role of such notions in the absence of a real moral community. A large discussion has been going on in recent years over whether the national identities have lost their significance and/or whether we should wish for them to disappear in the world of globalisation, large scale migration and multicultural societies. ${ }^{58}$ Since this issue cannot be explored here, I will simply assert without argument that national identities in many places, have not yet become obsolete. Where they have not, it is possible for the state to legitimately promote the common good of a given nation, even if in rather limited ways. For nations are not only (and in some cases at all)

54 A. MacIntyre, "Toleration...", p. 210.

55 A. MacIntyre, Dependent..., p. 133.

56 A. MacIntyre, "Politics, Philosophy...", p. 241.

57 To mention just a few examples: S. Benhabib, The Claims of Culture: Equality and Diversity in the Global Era, Princeton-Oxford 2002; J.H. Carens, The Ethics of Immigration, New York 2013; D. Miller, Citizenship and National Identity, Cambridge-Maldon 2005; K.C. Tan, Justice without Borders: Cosmopolitanism, Nationalism, and Patriotism, Cambridge-New York 2004.

58 See for example A. MacIntyre, Is Patriotism a Virtue? (The Lindley Lecture), University of Kansas 1984, p. 17. 
ethnic communities, they are also (at least potentially) political ones. Obviously not quite political in the Aristotelian sense, the distance between modern nations and pre-modern forms of political organisation like the Greek city-state is just too great. Nevertheless, nations are capable of governing themselves and pursuing at least some range of common goods with the use of the state apparatus.

I am thinking especially about the preservation of their languages. In order to support this view, I would like to enlist the help of no other than MacIntyre himself, since his attitude towards the nations is far from being unambiguous. He does subscribe to the view that nations are imaginary communities. ${ }^{59}$ This does not mean that they are not real, but rather that there is a specific mode of the constitution of a national identity: an ability to imagine oneself as a member of a given nation, English, Irish or Polish etc. But that imaginative identification must draw from a stock of common images and, symbols. These images and symbols are often at home in poetic and literary utterances in a national language. Historically the possession of a distinct language has also been one of the central features around which national identities arose. Therefore it seems evident that its preservation is a common good of a nation.

The same argument can be extended to the preservation of a national culture. Some of the works of art, historical events and monuments, etc. became so central to the national identity that it would be impossible to maintain its continuity without them. As MacIntyre notes: "Take away shared songs and poetry, shared monuments and architecture, shared imaginative conceptions of what is for this nation sacred ground and you at the very least weaken the bonds of nationality". ${ }^{60}$ He understands nations as historically extended projects in which the current generation tries to preserve, and in some cases to change, their understanding of what it means to be a member of a given nation for the posterity. ${ }^{61}$ Such a project could not go on without a reference point located in the nation's past. This does not imply an uncritical attitude to a cultural tradition and history of a nation, but neither does it necessitate its wholesale rejection.

There are however several qualifications that I would like to make in order to avoid potential misunderstanding. The preservation of national language and culture can be achieved, at least in some measure, without the use of state apparatus. There are historical examples of nations succeeding in this task against the official policies of the state they happened to be ruled by. So the active state engagement is not a necessary condition. It would even be dangerous to entrust this goal exclusively to the state. Nevertheless, virtually every nation, once it is able to form its own state, aspires to inculcate in the young generations of citizens the knowledge of its language and cultural heritage. But to attempt to do something does not equal to succeed. I am not suggesting that the states in general have been doing a good job. There is an obvious danger that through public education and other

59 A. MacIntyre, "Poetry as...", pp. 160-161.

60 Ibid., p. 161.

61 A. MacIntyre, Is Patriotism..., p. 14. MacIntyre also concedes that although an Aristotelian polity is not constituted by a common culture, it does indeed require bonds based on shared cultural heritage in order to survive. See idem, "Politics, Philosophy...", p. 241. 
means the state might strengthen chauvinistic attitudes and a sanitized, if not blatantly false, version of national history. My claim is much more modest, in that the state can contribute to the task of the preservation of language and culture and therefore can also promote the common good of a national community. Otherwise, I am fully in agreement with the spirit, if not quite the letter, of MacIntyre's remark that:

A national community [...] which systematically disowned its own true history or substituted a largely fictitious history for it or a national community in which the bonds deriving from history were in no way the real bonds of the community (having been replaced for example by the bonds of reciprocal self-interest) would be one towards which patriotism would be [...] an irrational attitude. ${ }^{62}$

Least of all I would like my arguments to be read as an attempt to romanticize the state in a Hegelian fashion as the highest form of ethical community. There is no reason why acknowledging that the state can do something to further a common good could not be combined with a recognition that it would be also desirable to decentralize some of its powers. The general tone of MacIntyre's suspiciousness towards the modern state seems warranted to me, but overdrawn. Modern states are indeed bureaucratic, coercive organisations which often deepen the injustices rather than remedy them. The question is whether it is all they are and can be?

\section{Conclusion}

Alasdair MacIntyre's examines the arguments elaborated in order to justify political obligation towards the modern state, a very specific form of political organisation, and finds them all unpersuasive. He concludes that political obligation towards it cannot be rationally justified. This is due to the essential characteristics of the modern state. Two of those characteristics crucial for MacIntyre's argument are: 1) the close partnership between the modern state and capitalism; 2) its bureaucratic and often unjustly coercive character which stems from the fact that the modern state does not represent or reflect an authentic moral community. Hence also the modern state is essentially incapable of realising any politics aimed at the common good of the whole polity. Whenever it claims to do so, it only provides an ideological façade for pursuit of some particular interests. This is also where MacIntyre locates the main point of contention between his own position and the one he attributes to theorists described as communitarians. While communitarians are generally favourable towards the modern state as a potential instrument of pursuing the common good, MacIntyre maintains that it is only at the level of small-scale, local communities that the authentic politics of common good can be realized.

The question for those generally sympathetic to MacIntyre is the following: does his ambitious and powerful retelling of the history of Western morality also necessitate adopting his conclusions in the field of political theory? Although MacIntyre's critique of the modern state does contain some important insights, it does

62 A. MacIntyre, Is Patriotism..., p. 16. 
not warrant the position of radical antistatism. In my view the nation states can foster the common goods of nations, mainly by helping to preserve their languages and cultures. While there is no reason to put exaggerated trust in the state's operations, as for instance some of MacIntyre's followers in Poland tend to, the task of restoring politics aimed at the common good might very well turn out to be incoherent and impractical if the possibility of involving the state in it is wholly discredited from the outset.

\section{References}

Bartels L.M., Unequal Democracy: The Political Economy of the New Gilded Age, Princeton 2016 (2008).

Beiner R., "Community versus Citizenship: MacIntyre's Revolt against the Modern State", Critical Review: A Journal of Politics and Society 14 [4] (2000), pp. 459-479, DOI: https://doi.org/10.1080/08913810008443569.

Benhabib S., The Claims of Culture: Equality and Diversity in the Global Era, Princeton-Oxford 2002.

Breen K., "The State, Compartmentalization and the Turn to Local Community: A Critique of the Political Thought of Alasdair MacIntyre", The European Legacy 10 [5] (2005), pp. 485-501, DOI: https://doi.org/10.1080/10848770500173722.

Carens J.H., The Ethics of Immigration, New York 2013.

Estlund D., Democratic Authority, Princeton-Oxford 2008.

Frank N., "Against Normative Consent", Journal of Social Philosophy 47 [4] (2016), pp. 470-487, DOI: https://doi.org/10.1111/josp.12174.

Gilens M., Page B.I., "Testing Theories of American Politics: Elites, Interest Groups, and Average Citizens", Perspectives on Politics 12 [3] (2014), pp. 564-581, DOI: https://doi.org/10.1017/S1537592714001595.

Hibbs T.S., "MacIntyre, Aquinas, and Politics", The Review of Politics 66 [3] (2004), pp. $357-383$.

Horton J., Political Obligation, London 1992.

Klosko G., Political Obligations, New York 2005.

Kołakowski L., "The Myth of Human Self-Identity. Unity of Civil and Political Society in Socialist Thought", [in:] The Socialist Idea: A Reappraisal, L. Kołakowski, S. Hampshire (eds.), London 1974, pp. 18-35.

Lewis V.B., "The Common Good against the Modern State? On MacIntyre's Political Philosophy", Josephinum Journal of Theology 16 (2009), pp. 357-378.

MacIntyre A., After Virtue. A Study in Moral Theory, Notre Dame 2007 (1981).

MacIntyre A., Dependent Rational Animals, Chicago-La Salle 1999.

MacIntyre A., Ethics in the Conflicts of Modernity: an Essay on Desire, Practical Reason and Narrative, Cambridge 2016.

MacIntyre A, "I'm not a Communitarian, but...", The Responsive Community 1 [3] (1991), pp. 91-92.

MacIntyre A., Is Patriotism a Virtue? (The Lindley Lecture), University of Kansas 1984. 
MacIntyre A., "Philosophy and Politics", [in:] Philosophy and Human Enterprise, USMA Class of 1951 Lecture Series, 1982-3, West Point 1984, pp. 131-160.

MacIntyre A., "Poetry as Political Philosophy: Notes on Burke and Yeats", [in:] A. MacIntyre, Ethics and Politics. Selected Essays, Vol. 2, Cambridge 2006, pp. 159-171.

MacIntyre A., "Politics, Philosophy and the Common Good", [in:] The MacIntyre Reader, K. Knight (ed.), Notre Dame 1998, pp. 235-252.

MacIntyre A., "Some Enlightenment Projects Reconsidered", [in:] A. MacIntyre, Ethics and Politics. Selected Essays, Vol. 2, Cambridge 2006, pp. 172-185.

MacIntyre A., "The Theses on Feurbach: a Road not Taken", [in:] The MacIntyre Reader, K. Knight (ed.), Notre Dame 1998, pp. 223-234.

MacIntyre A., "Three perspectives on Marxism: 1953, 1968, 1995", [in:] A. MacIntyre, Ethics and Politics. Selected Essays, Vol. 2, Cambridge 2006, pp. 145-158.

MacIntyre A., "Toleration and the Goods of Conflict", [in:] A. MacIntyre, Ethics and Politics. Selected Essays, Vol. 2, Cambridge 2006, pp. 205-223.

Michels R., Political Parties: a Sociological Study of the Oligarchical Tendencies of Modern Democracy, New Brunswick 1999 (1962).

Mill J., "Government", [in:] The Political Writings of James Mill: Essays and Reviews on Politics and Society, 1815-1836, D.M. Hart (ed.), Indianapolis, IN 2013, pp. 262-296, http://oll-resources.s3.amazonaws.com/titles/2520/Mill_1624_EBk_ v7.0.pdf.

Miller D., Citizenship and National Identity, Cambridge-Maldon 2005.

Murphy M.C., "MacIntyre's Political Philosophy", [in:] Alasdair MacIntyre, M.C. Murphy (ed.), Cambridge 2003, pp. 152-175.

Osborne T., "MacIntyre, Thomism and the Contemporary Common Good", Analyse E Kritik 30 [1] (2008), pp. 75-90, DOI: https://doi.org/10.1515/auk-2008-0105.

Simmons A.J., Moral Principles and Political Obligations, Princeton 1979.

Tan K.C., Justice without Borders: Cosmopolitanism, Nationalism, and Patriotism, Cambridge-New York 2004.

Weber M., The Protestant Ethic and the Spirit of Capitalism, London-New York 2001. Wolff R.P., In Defense of Anarchism, Berkley-Los Angeles-London 1998 (1970). 